\title{
Covid-19 Gölgesinde Çalışmanın Geleceği Tartışmaları ve Avrupa Birliği'nde Kamusal Sosyal Harcamalar
}

\author{
Future of Work Discussion under the Shadow of Covid-19 and European Union's \\ Social Protection Expenditures
}

\section{UMUT YERTÜM*}

* Res. Asst. Dr., Kırklareli University, FEAS, Department of Labour Economics and Industrial Relations, Kayalı Campus, Kofçaz Yolu Üzeri, B Blok, Kat 3, 39000 Kırklareli, Turkey, Email: umutyertum@klu.edu.tr (D) https://orcid.org/0000-0003-1548-264X

Öz: 1970'li yıllardan itibaren post-endüstriyel toplum teorisyenleri tarafindan sıklıkla tartışlan çalıșmanın geleceği olgusu teknolojinin istihdam üzerindeki etkilerine odaklanmaktadır. Teknolojinin emek talebini azaltması, ișsizlik artıșı ile sonuçlanmıștır. Bu çalışmanın amacı Covid-19 ile mücadelede gündeme gelen devlet müdahalesi, AB'deki yansımaların incelemektir. Bu amaçla, Avrupa Konseyi, SURE programı ve Eurostat verileri incelenmiștir. Yapılan incelemede Covid-19 nedeniyle AB 27 ülkelerinde ortalama ișsizlik 2019 yllinda \%6,8'den 2020 yllinda \%7,2'ye yükselirken, istihdam ayn dönemlerde \%68,4'ten $\% 67,4$ 'e düsmüs; kamusal harcamalar ise \%46,6'dan \%53,4'e yükselmiștir. Son olarak Covid19 ile etkin mücadele için 2,364 trilyon $€$ değerinde ortak fon oluşturan AB, işgücü piyasalarındaki etkisi azaltmak ve daha etkin mücadele için kurduğu SURE programına katılan 30 milyon çalışan ve 2,5 milyon işletmeye destek için 94 milyar € fon kullanmıştır.

Anahtar kelimeler: Covid-19, Post-endüstriyel toplum, İstihdam, İssizlik, SURE programı, Kamusal harcamalar

Abstract: The phenomenon of the future of work, which has been frequently discussed by post-industrial society theorists since the 1970s, focuses on the effects of technology on employment. Unemployment, which is at the forefront of these effects, and the public intervention necessary to combat it form the basis of these discussions. The aim of this study is to examine the reflections of the state intervention in the fight against Covid-19 in the EU. For this purpose, the data of the Council of Europe, the SURE program and Eurostat were examined. In the review, the average unemployment in $E U 27$ countries increased from $6.8 \%$ in 2019 to $7.2 \%$ in 2020 due to Covid-19, while employment decreased from $68.4 \%$ to $67.4 \%$ in the same periods; public expenditures increased from $46.6 \%$ to $53.4 \%$. Finally, the EU, which created a joint fund of $€ 2,364$ trillion for the effective fight against Covid-19, used $€ 94$ billion funds to support 30 million employees and 2.5 million businesses participating in the SURE program, which it established to reduce the impact in the labor markets and to fight more effectively.

Keywords: Covid-19, Post-Industrial Society, Employment, Unemployment, Public expenditure, SURE programme 


\section{Giriş}

Teknolojinin gelişmesi ve çalışma hayatını derinden etkilemesi tartışmaları çok eskilere dayanmış olsa da modern anlamda çalışmanın geleceği tartışmalarının endüstri devrimi ile başladığını söylemek yerinde olacaktır. Tarih boyunca teknoloji, üretimin verimli hale gelmesini sağlarken, işgücünün hem niceliğini hem de niteliğini etkilemiştir. Öyle ki teknolojik gelişim kitlesel üretimin baskın olduğu 19451975 yılları arasında istihdamın artmasını sağlarken, 1975 sonrası ise artan rekabet baskısı ile istihdamın niteliğini değiştirerek işgücü talebinin azalmasına neden olmuştur. Başka bir ifade ile anlatılacak olursa, teknolojinin üretimde kullanılabilir olması, kimi zaman istihdamı arttırmış kimi zaman ise istihdamı baskılayarak işsizliğe neden olmuştur. Tüm bu etkileri bir tarafa bırakılırsa, teknolojinin gelişimi bir yandan üretim maliyetlerinin düşürülmesine diğer yandan üretim miktarlarının arttırılmasına imkân tanımıştır.

Çalışmanın geleceği tartışmaları ise genel olarak teknolojinin üretimde kullanılmasının neticesinde; insan emeğine olan talebin zamanla azalarak ortadan kalkacağ 1 varsayımlarına odaklanmaktadır. Post-endüstriyel toplum teorisyenleri, endüstri toplumuna özgü üretimin yerini Daniel Bell’in ifade ettiği gibi bilgi ekonomisi, Gorz'un ifade ettiği gibi maddesiz üretim, Toffler' in ifade ettiği gibi prosumer (üreten tüketici) ya da Rifkin'in ifade ettiği gibi çalışmanın olmadığı topluma bıraktığını ifade etmektedir. Tüm bu tanımlamaların ortak yönünü; tam zamanlı ve güvenceli işlere olan talebin zamanla azalarak ortadan kalkacağı oluşturmaktadır.

2000’li yıllardan itibaren özel sektör istihdamı ve üretim verimliliği arasındaki ilişkinin ortadan kalktığına yönelik bilimsel çalışmalar sıklaşmış ve üretimin arttırılması için istihdama değil teknolojiye yatırımın daha ekonomik olduğu vurgulanmıştır. 2010'lu yılların başından itibaren yapay zekâ, nesnelerin interneti, mikro sensörler, sürücüsüz araçlar, karanlık fabrikalar, platform ekonomileri vb. yeni teknolojilerin sosyal hayatta baskın olduğu bir dönem başlamıştır. Klaus Schwab'in Sanayi 4.0 olarak tanımladığı bu yeni üretim modelinde insan emeğine olan talep azalırken; birçok üretim modelinde insan emeği üretimden tamamen çıkarılmıştır.

Sanayi 4.0 tartışmaları devam ederken; 2019 yılı Mart ayında Çin'in Wuhan eyaletinde patlak veren Covid-19 pandemisi ise karantina ve tam kapanma uygulamaları nedeniyle sosyal hayat durma noktasına gelmiştir. Tam kapanmaların yaygınlaşması ile ise birçok sektörde üretim tamamen durmuştur. Sosyal ve ekonomik alanda meydana gelen bu gelişmeler ise emek talebini düşürerek geçici de olsa kitlesel bir işsizliğe neden olmuştur.

Öyle ki, Uluslararası Çalışma Örgütü (ILO) verilerine göre Covid-19 pandemisi, 250 milyon tam zamanlı istihdamın ortadan kalkmasına neden olmuştur. Rifkin'in 2050 yılı itibariyle sosyal soruna dönüşeceğini iddia ettiği kitlesel işsizlik, Covid-19 ile 2020 yılında tüm dünyayı tehdit eden boyutlara ulaşmıştır.

Post-endüstriyel teorisyenler tarafından dile getirilen; teknolojik gelişmenin emek talebini azaltarak kitlesel işsizliğe neden olacağı vurgusu Covid-19 pandemisi ile tekrar gündeme gelmiş ve yaşanan geçici işsizlik sürecinde kamu müdahalelerinin yeterliliği tartışılmaya başlanmıştır. Geçici işsizliğin yaygınlaştığı bu süreçte bazı ülkeler tüm kesimleri kapsayacak şekilde doğrudan nakdi destek programlarına başvururken; bazı ülkeler aktif işgücü piyasası uygulamalarını devreye sokarak etkileri azaltma yolunu seçmiştir. 
İşgücü piyasalarında var olan işsizliğin azaltılmasına yönelik politikalar, ekonomik kriz ya da savaş gibi olağanüstü durumlarda uygulanamamaktadır. İstihdamın desteklenmesi için gerekli şartların başında uygun bir sosyo-ekonomik konjonktür gerekmektedir.

İşte bu çalışma Covid-19 gibi tüm dünyayı etkisine alan pandemiyle mücadele yöntemlerine odaklanmaktadır. Pandemi nedeniyle azalan işgücü talebin nedeniyle başvurulan kamusal sosyal harcamalara ve müdahalelere odaklanmaktadır. Bu amaçla; Avrupa Konseyi, Eurostat ve SURE programına ait veriler analiz edilmiştir.

\section{Çalışmanın Geleceği Tartışmaları}

Teknolojinin hızla gelişerek çalışma hayatını etkileyeceği ve dolayısıyla talep edilen işgücü talebini etkileyeceği varsayımları sanayileşmenin yoğunlaşmaya başladığı 19. Yüzyılın başından itibaren yaygınlık kazanmış olsa da etkilerine yönelik ilgi daha eskilere gitmektedir. Sanayileşmenin ivme kazanmasıyla insanların kırsal alandan kentsel alanlara göçü, kentlerde farklı taleplerin oluşmasına neden olmuştur. Adam Smith, din görevlileri, oyuncular, avukatlar ve sanatçıların üretmiş olduğu hizmetleri verimsiz nitelendirerek, verimli emeğin sadece sanayi üretimi olduğunu vurgulamıştır. ${ }^{1}$

Hizmetler sektörü özelinde verimli ve verimsiz emek tartışmaları 1930'lu yıllara kadar devam etmiştir. Bu yıllarda talep edilen hizmetlerin çoğunluğu lüks olarak nitelendirilmiş, verimlilik tarım ve sanayi sektörlerine atfedilmiştir. Bu iki sektör dışında üçüncü bir sektörün varlığı 1930'lu yılların sonundan itibaren yapılan akademik çalışmalarda kendisine yer bulabilmiştir. Allan Fisher, Jean Fourastie ve Colin Clark yaptıkları çalışmalarla bu alandaki öncülüğü ele almıştır. ${ }^{2}$ Hizmetler sektörüne yönelik akademik çalışmalar bu dönemde başlamış olsa da bugün atfedilen değer söz konusu olmamıştır.

Bu çalışmalarda hizmetler sektörü üçüncü bir sektör olarak kabul edilse de hizmetler sektöründeki verimliliğin istatistiksel olarak ölçümü zor olduğu için verimsiz olarak nitelendirilmiştir. Hizmetler sektörü ile tarım-sanayi sektörleri arasında sistemli bir verimlilik farkından bahsedilemeyeceğini, daha önceki çalışmasını 1960 yılında güncelleyerek, ilk defa Colin Clark ifade etmiştir. ${ }^{3}$

Hizmetler sektörünün tarım ve sanayi gibi üçüncü bir sektör olarak kabul görmesi, istihdamın sanayi sektöründen hizmetler sektörüne kayması ile birleşince, çalışmanın geleceği tartışmalarını alevlendirmiştir. Teknolojinin başlangıçta pahalı ve uygulanabilirliğinin sınırlı olması, tartışmaların büyümesini kısmen engellese de teknolojinin ucuzlamasıyla tartışmalar kaldığg yerden devam etmiştir.

Teknolojik gelişmelerin üstel bir gelişime sahip olduğunu ifade eden Gordon Moore, 1965 yılında yayınladığı makalede bilgisayar üretiminde kullanılan çiplerden yola çıkarak bir hesaplama yapmıştır. Bu hesaplamaya göre teknolojide meydana gelen gelişmeler ortalama 2 yılda bir katlanarak devam etmektedir. Moore Yasası olarak da bilinen bu hesaplamalara göre teknolojik kapasite düzeyi bir yandan iki

\footnotetext{
${ }^{1}$ Adam Smith, "An Inquiry into the Nature and Causes of the Wealth of Nations", Adam Smith, Der. Edwin Cannan, 1904, s.440, https://www.journals.uchicago.edu/doi/10.1086/251119.

${ }^{2}$ Jean-Claude Delaunay ve J. Gadrey, Services in Economic Thought: Three Centuries of Debate, International Studies in the Service Economy, vol. 3. Boston: Kluwer Academic Publishers, 1992, s.75.

${ }^{3}$ Delaunay ve Gadrey, 154-55.
} 
yılda bir iki katına çıkarken, diğer yandan ucuzlayarak tabana yayılmaktadır. ${ }^{4} \mathrm{Bu}$ durum genelde toplumsal hayatı özelde ise çalışma hayatını radikal bir biçimde etkilemektedir.

Teknolojik gelişimin süreklilik sağlaması çalışma hayatına etkisini de hızlandırmıştır. Nitekim Keynes Torunlarımızın Önündeki Ekonomik Olasılıklar adlı makalesinde bu durumu incelemiş ve teknolojinin işsizliğe neden olacağı uyarısında bulunmuştur ${ }^{5}$. Benzer şekilde Leontief de Keynes gibi teknoloji tartışmalarına katılarak; traktörün icadından sonra atlara olan talebin önce azaldığı sonra ortadan kalktığını belirterek, insan emeğine olan talebin de teknolojideki gelişmelerle ters orantılı olarak önce azalacağı sonra ortadan kalkacağ 1 uyarısında bulunmuştur. ${ }^{6}$

\section{Post-Endüstriyel Toplum}

Teknolojinin genelde toplumsal hayatı özelde ise çalışma hayatını ters yüz edeceği tartışmaları eskilere dayansa da endüstri toplumunun miadını doldurduğu vurgusunu ilk önce Daniel Bell yapmıştır. Bell yapmış olduğu çalışmaların büyük çoğunluğunda istihdam ve onun dönüşümüne odaklanmıştır. 1947 yılında kaleme aldığ 1 Adjusting Men to Machines adlı eserinde tarım-sanayi sektörlerinin dışında yeni bir sektörün oluştuğuna ve teknolojinin buna adapte edilmesine önem verilmesi gerektiğine vurgu yapmaktadır. ${ }^{7}$

1940’lı yıllardan itibaren çalışmanın dönüşümüne odaklanan Bell, Colin Clark tarafından yapılan çalışmaları referans alarak üçlü sektör tanımlamasını yapmış ve ilk defa post-endüstriyel toplum kavramını kullanmıştır. 1973 yılında yayınladığ 1 The Coming of Post-Industrial Society adlı çalışmasında ise; buhar gücü, elektrik ve gazdan enerji elde edilmesinin endüstri toplumunun temeli olduğunu fakat post-endüstri toplumunda bunun çok daha farklı ve fazla katmandan meydana geldiğini ifade etmektedir. Bell'e göre ilk ve en önemli geçiş imalata dayalı üretimden hizmetler sektörüne geçişte yaşanacaktır. Bu geçişle istihdam edilenlerin büyük bir bölümü sanayiden hizmetler sektörüne geçecektir. Bell'e göre post-endüstriyel toplumda görülecek en önemli değişimlerden bir diğeri bilgi değer teorisidir. Klasik iktisatçılar tarafından endüstri toplumu emek değer teorisine dayanırken postendüstriyel toplumda bu değişmektedir. Buna göre artık yenilik yaratmanın kaynağı bilgidir ve bilgi teknolojisi ile bilgiyi kullanan herkesin hayatı sonsuza dek değişecektir. ${ }^{8}$

Bell, post-endüstriyel dönüşümü tanımlayıp ortaya çıkan toplumu ve bu toplumun çalışma olgularını sosyolojik bir bakışla incelerken, Andre Gorz daha radikal bir tavır takınarak çalışma olgusuna ve maddesiz üretimin yükselişine odaklanmıştır. Gorz, gerçekleşen dönüşümleri sosyalizm ya da kapitalizmle açılamanın güçlüğüne değinerek; post-endüstriyel toplumu bu iki akımın ötesinde bir yere konumlandirmaktadır.

\footnotetext{
4 "Moore's Law: Computer Science", Encyclopedia Britannica, erişim 10 Ocak 2020, https://www.britannica.com/technology/Moores-law.

${ }^{5}$ John Maynard Keynes, "Economic Possibilities for Our Grandchildren (1930)", Essays in Persuasion, New York: Harcourt Brace, 1932.

${ }^{6}$ Wassily Leontief, "National Perspective: The Definition of Problems and Oppurtinities”, içinde The longTerm Impact of Technology on Employment and Unemployment, Washington: National Academies Press, 1983, s.3-4.

${ }^{7}$ Malcolm Waters, Key Sociologists: Daniel Bell, Routledge, 2002, s.12-13.

${ }^{8}$ Daniel Bell, The Coming of Post-Industrial Society: A Venture in Social Forecasting, Special Anniversary ed New York: Basic Books, 1999, s.14-18.
} 
Adam Smith'ten beri değer kaynağı olarak kabul edilen soyut emeğin post-endüstriyel toplumda yerini karmaşık emeğe bıraktığını ifade eden Gorz, zaman birimi ile ürün biriminin çarpımından elde edilen maddi üretimin yerini maddesiz üretime bıraktığını ifade etmektedir. ${ }^{9}$ Gorz da Bell gibi bilgiye vurgu yaparak, bilgi ekonomisi olgusunu ön plana çıkarmaktadır. Maddesiz üretim olarak adlandırdığ 1 bilgi ekonomisine göre; post-endüstriyel toplumda bilgi bir kere üretildikten sonra yeniden üretmek için katlanılan maliyet sıfıra yakındır. Bu yüzden bilgi ekonomisinde üretmenin maliyeti hiçbir zaman ilk üretim maliyeti ile ilişkili olmayacaktır. Gorz’a göre değerli olan bilgi değil, bilgiye erişimdir. Bilginin üretimde maliyetleri düşürmesi, bir yandan ürünlerin ucuzlamasına diğer yandan üretimde talep edilen emeğin azalmasına neden olmaktadır. ${ }^{10}$

Bell'in aksine Gorz, çalışmanın geleceğine yönelik daha net bir açıklama getirerek; büyük zenginlik kaynağı olarak görülen doğrudan emeğin bu özelliğini kaybettiğini dolayısıyla zenginliğin ölçümünde de kullanılamayacağını ifade etmektedir. Yine Gorz’a göre post-endüstriyel toplumda çalışma sürelerinin mübadele değerinin anlamını yitirdiği için refah, üretim ve çalışma ilişkilerinin yeniden kurulması gerekmektedir. ${ }^{11}$

Gorz, istihdam ve üretim ilişkilerinin geleceğini yorumlarken, bildiğimiz anlamda çalışma olgusunun sonuna geldiğimizi belirtmektedir. Gorz'a göre endüstri toplumu ya da diğer bir ifade ile çalışma uygarlığının dayattığı normların sonuna gelindiği için post-endüstriyel toplumun bunu tartışmaya başlaması gerekmektedir. Gorz, endüstriyel çalışmanın sonuna geldiğimizi ifade ederken, yaratıcılık anlamındaki çalışmanın ise devam edeceğini belirtmektedir. ${ }^{12}$

Endüstriyel çalışmanın zamanla ortadan kalkacağından hareketle Gorz, var olan işlerin çalışmak isteyenler arasında bölüştürülmesinin bir tercihten öte zorunluluk haline geldiğini belirtmektedir. Gorz’a göre teknolojinin her geçen gün otomasyona imkân vermesi ile talep edilen emek buna paralel olarak azalacak ve bunun bir sonucu olarak da toplumda işsiz sayısının sürekli artacaktır. Gorz, toplumsal barışın sağlanması, işsizlerin ve kamusal desteğe bağımlı birey sayısının azalması için çalışmanın bölüştürülmesinin elzem olduğunu ileri sürmektedir. ${ }^{13}$

Çalışmanın geleceği tartışmalarına 1970’li yıllardan itibaren dâhil olan Alvin Toffler ise toplumu binlerce yıl önce başlayıp 18. yüzyılda da devam eden birinci dalga, 1650-1750 yılları arasında başlayıp 1960 yılına kadar devam eden ikinci dalga ve 1960 yılından günümüze devam eden üçüncü dalga olarak sınıflandırmaktadır. Toffler'e göre birinci dalga tarım, ikinci dalga endüstri ve üçüncü dalga da hizmetler sektörünün toplumun itici gücü olduğu bir dönüşümü temsil etmektedir. ${ }^{14}$ Toplumun üretim ilişkilerini inceleyen Toffler'e göre birinci dalga toplumun modern anlamda üretici ve tüketici ayrımı yokken, endüstri devrimi ya da ikinci dalga toplumu ile bu ayrım ortaya çıkmıştır. Üretici ve tüketicinin kesin çizgilerle birbi-

\footnotetext{
${ }^{9}$ André Gorz, Maddesiz: Bilgi Değer ve Sermaye, çev. Işık Ergüden, İstanbul: Ayrıntı, 2011, s.2-9.

${ }^{10}$ Gorz, Maddesiz: Bilgi Değer ve Sermaye, s.34-37.

${ }^{11}$ André Gorz, Elveda Proletarya, çev. Hülya Tufan, İstanbul: AFA Yayınları, 1986, s.200-201.

${ }^{12}$ André Gorz, Yaşadığımız Sefalet: Kurtuluş Çareleri, İstanbul: Ayrıntı, çev., Nilgün Tutal Cheviron, 2001, s.11-12.

${ }^{13}$ Andre Gorz, Kapitalizm, Sosyalizm, Ekoloji: Yönelim Bozuklukları, Arayışlar, çev. Işık Ergüden, İstanbul: Ayrint1, 1993, s.40-50.

${ }^{14}$ Alvin Toffler, Üçüncü Dalga, çev. Ali Seden, İstanbul: Altın Kitaplar, 1996, s.30-33.
} 
rinden ayrılması insanlık tarihinin o güne kadar görmüş olduğu en verimli toplumunun doğmasına neden olmuştur. Toffler'e göre ikinci dalga toplumu kadar üretip bunun satışı için mücadele eden bir toplum daha önce var olmamıştır. ${ }^{15}$

Toffler'e göre 1960'lı yıllarda ivmelenen teknolojik gelişmeler üçüncü dalga toplumlarını oluştururken, ikinci dalga toplumu ile birbirinden kesin çizgilerle ayrılan üretici ve tüketici ilişkisini tekrar belirsizleştirmiştir. Toffler, kişilerin uzman ihtiyacı hissetmeden temel konularda üretime tekrar katılmasının birinci dalga toplumuna dönüş olduğunu belirtmektedir. Toffler' in prosumer (üreten tüketici) olarak adlandırdığı yeni kültür esas itibariyle tarım toplumunda olduğu gibi kişilerin tükettikleri ürünlerin bir kısmını ürettikleri bir süreci ifade etmektedir. Toffler'e göre petrol krizlerinden önce istasyonların neredeyse tamamında pompacı bulunurken, krizlerden sonra maliyet düşürmek için benzin istasyonların yarısı kendin yap hizmete geçerek pompacı istihdamını sonlandırırken, kendin yap tarzı tüketim hızla artmıştır. Teknoloji bir yandan üretimi ve üretime katılımı kolaylaştırırken diğer yandan talep edilen istihdamın azalmasına neden olmaktadır. Toffler'e göre üçüncü dalga toplumunun baskın hale gelmesiyle birlikte insanların ikinci dalga toplumundaki gibi tam gün prensibiyle çalışmayacağı ve dolayısıyla çalışma sürelerinin hızla azalacağı bir dönem başlayacaktır. 1980’li yıllara ait istatistikleri inceleyen Toffler, işgücüne katılma oranlarının artarken kişi başına düşen çalışma saatlerinin bunun bir sonucu olduğunu belirtmektedir. ${ }^{16}$

Çalışmanın geleceğine yönelik radikal fikirlere sahip bir diğer post-endüstriyel toplum teorisyeni Jeremy Rifkin ise 1994 yılında yayınladığı Çalışmanın Sonu (End of the Work) adlı eseriyle endüstri toplumuyla baskın hale gelen bildiğimiz anlamda çalışmanın sonuna gelindiği ve toplumumuzun buna uyum sağlamasının önemine vurgu yapmaktadır. Rifkin'e göre insanlık tarihindeki tüm medeniyetler çalışma olgusuna göre yapılandırılmıştır. Batılı ülkelerde; eski çağdaki çiftçiden orta çağdaki zanaatkâra ve endüstri dönemindeki mavi-yakalı işçilere kadar tüm dönemde çalışma bir yapı taşı görevi görmüştür. Rifkin'e göre endüstri toplumunda üretim kapasitesini zirveye çıaran Fordist üretim tarzı yarım asır sonra piyasadan çekilmeye başlamıştır. Rifkin, teknolojinin gelişmesiyle birlikte insanlık tarihinde ilk defa, üretimde insan emeğine olan talebin sistemli bir şekilde azaltılabilme imkânı doğduğunu belirtmektedir. Teknolojinin gelişim hızı ilk önce mavi yakalılara olan talebi daha sonra ise beyaz yakalı talebini azaltarak işsizliğe neden olacaktır. ${ }^{17}$

Klaus Schwab ise yaşanan dönüşümleri 4 farklı aşamada açılama yoluna giderek, günümüzün toplumunun Sanayi 4.0 aşamasında olduğunu belirtmektedir. Schwab'a göre buhar makinesi Sanayi 1.0'1, kitlesel üretim ve elektrik Sanayi 2.0'1, elektronik ve otomasyon Sanayi 3.0'1 ve son olarak siber sistemler ve nesnelerin interneti Sanayi 4.0 aşamalarını simgelemektedir. Schwab'a göre yapay zekâ, mobil internet ve makine öğrenmesi gibi mikro teknolojik gelişmeler üstel bir devrimin sonucunu oluşturmakta ve çalışma ilişkilerini derinden sarsmakatadır. Schwab’a göre teknolojinin gelişmesi bir yandan verimlilikte insan emeğine olan talebi azaltırken diğer yandan bazı mesleklerin ortadan kalkmasına neden olmaktadır. ${ }^{18}$

\footnotetext{
${ }^{15}$ Toffler, Üçüncü Dalga, s.165-166.

${ }^{16}$ Toffler, Üçüncü Dalga, s.335-350.

${ }^{17}$ Jeremy Rifkin, The End of Work: The Decline of The Global Labor Force and the Dawn of the Post-Market Era, New York: G.P. Putnam's Sons, 1995, s.2-3.

${ }^{18}$ Klaus Schwab, Dördüncü Sanayi Devrimi, çev. Zülfü Dicleli, İstanbul: Optimist, 2017, s.11-17.
} 
Schwab 2018 yılında yayınladığı yeni eserinde ise daha karamsar bir resim çizerek; teknolojinin önceki dönemlere göre daha az iş oluştururken, önceki dönemlerle kıyaslanmayacak düzeyde var olan işleri ortadan kaldırdığını belirtmektedir. Daha da önemlisi, oluşturulan işlerin büyük çoğunluğunun gig ekonomisi olarak adlandırılan a-tipik ya da güvencesiz işler olduğunu vurgulamaktadır. Schwab’a göre tarih boyunca verimlilik ve üretim arasında köprü görevi gören emek talebi hızla azalmaya başlamıştır. ${ }^{19}$

Verimlilik ile özel sektör istihdamının yıllar itibariyle gelişimi inceleyen Bernstein, 2000'li yıllara kadar verimlilik ve istihdam birlikte hareket etseler de daha sonraki süreçte aralarındaki ilişkinin koptuğu ifade etmektedir. ${ }^{20}$

Brynjolfsson ve Mcafee yapmış oldukları çalışmada GSYH içindeki ücretlilerin oranı ile şirket karları arasındaki ilişkiye odaklanmıştır. Yaptıkları çalışma sonucuna göre 2000'li yıllara kadar ücretlilerin GSYH içindeki payı şirket paylarından fazlayken, 2000'li yıllardan itibaren bu ilişki bozulmuş ve şirket payları lehine yeni bir düzen oluşmuştur. 2002 yılında ücretlilerin payı \%49’ken, şirketlerin payı \%45 olarak gerçekleşmiş, 2012 yılına gelindiğinde ise ücretlilerin payı \%43'e düşerken şirketlerin payı \% 49 'a yükselmiştir. Buradan hareketle teknolojinin insan emeğine olan talebi nasıl azalttığını görmek mümkün olmakla birlikte; Brynjolfsson ve Mcafee'e göre insan emeğine olan talep azalmasına rağmen henüz tamamen ortadan kalkmamıştır. $^{21}$

Çalışmanın geleceğine yönelik teorilerin büyük çoğunluğu endüstri toplumuna özgü tipik çalışmanın sonuna gelindiğine ya da gelmek üzere olduğuna odaklanmaktadır. Post-endüstriyel toplum teorisyenleri, klasik anlamda çalışmanın ortadan kalkması ile toplumda meydana gelebilecek işsizlikle bağlantılı sosyal sorunlara dikkat çekerek, kamu müdahalesinin zorunluluğuna vurgu yapmaktadır. Çalışmanın geleceği tartışmalarının kamu müdahalesinin sürekli dile getirilmesine rağmen; bu müdahaleye yakın gelecekte ihtiyaç olmadığı varsayılmaktadır. Örneğin Jeremy Rifkin, bildiğimiz anlamda çalışmanın 2050 yılı itibariyle ortadan kalkacağını ifade etmektedir.

Bununla birlikte kamu müdahale çeşitleri ise genellikle çalışmanın, çalışmak isteyen tüm paydaşlar arasında bölüştürülmesi ya da temel gelir gibi sürekli nakdi destek uygulamaları etrafında şekillenmektedir. İşsizlik yardımı, işsizlik maaşı ya da şartsız temel gelir pasif işgücü piyasası politikalarını oluştururken; istihdamın paylaştırılması, çalışma sürelerinin kısaltılması ya da kamu istihdam arttırma uygulamaları aktif işgücü piyasası politikalarını oluşturmaktadır.

Örneğin literatüre Finlandiya Deneyi olarak giren uygulamada; Finlandiya hükümeti 2017-2018 yılları arasında 2 bin kişiye herhangi bir şart aranmaksızın aylık ortalama $560 €$ maaş bağlamıştır. Bu kişilerin temel gelir sonrası işgücü piyasalarındaki tavırları incelenerek; işsizlik maaşı alanlar ile kıyas yapılmıştır. Deney grubundaki bireyler ücret karşılığı çalışmaları vb. durumlarda dahi temel gelir almaya devam etmiştir. Finlandiya deneyindeki amaç bireylerin temel gelir kaygısı olmadığı

${ }^{19}$ Klaus Schwab ve Nicholas Davis, Shaping the Future of the Fourth Industrial Revolution, New York: Currency Book, 2018, s.38-41.

${ }^{20}$ Jared Bernstein, “Getting Back to Full Employment: On the Economy”, On the Economy: Jared Bernstein Blog, erişim, 5 Ağustos 2020, http://jaredbernsteinblog.com/getting-back-to-full-employment/.

${ }^{21}$ Erik Brynjolfsson ve Andrew Mcafee, İkinci Makine Çăğ: Akıllı Teknolojiler Devrinde Çalışma, İlerleme ve Refah, çev. Levent Göktem, İstanbul: Türk Hava Yolları Yayınları, 2014, s.170-238. 
takdirde işgücü piyasaları ile olan ilişkilerini incelemektir. Yapılan deneyin sonunda karşılıksız temel gelir alan bireylerin yılda ortalama 78 gün çalıştıkları tespit edilirken; işsizlik yardımı alan ve toplam sayıları 190bin olarak kişilerden sadece 6 gün daha fazla çalıştıkları görülmüştür. Bununla birlikte; temel gelir alan bireylerin işsizlik yardımı alan kişilere kıyasla; daha mutlu oldukları, zihinsel ve bilişsel sağlıklarının daha iyi olduğu saptanmıştır ${ }^{22}$. Başka bir ifade ile temel gelir alan bireylerin işgücü piyasalarına etkisi sınırlı olmuştur.

Temel gelir programlarının yüksek maliyeti, ülkelerin çalışma saatlerini düşürerek istihdamı paylaştırma ya da kamu istihdam politikaları yoluyla işsizliği azaltma yolunu tercih etmelerine neden olmaktadır. Düşük maliyeti ve sürdürülebilir olması aktif işgücü piyasası politikalarını ön plana çıkarmaktadır. Aktif işgücü piyasası politikaları; istihdam yaratıldığı oranda başarılı olabilmektedir. Ekonomik kriz, savaş vb. olağanüstü dönemlerde ise kamunun tek müdahale aracı gelir destek programları olmaktadır. Nitekim benzer bir müdahale ihtiyacı, tam kapanma ya da karantina dönemlerinde istihdam yaratarak işsizliği azaltmanın mümkün olmadığ 1 Covid-19 Pandemisi ile gündeme gelmiştir.

\section{Covid-19 Salgını ile Mücadelede Avrupa Birliği Sosyal Harcamaları}

2019 yılı sonlarında Çin'de patlak veren Covid-19 Pandemisi 2020 yılında tüm Avrupa coğrafyasında emek talebinin azalmasına ve işsizliğin artmasına neden olmuştur. Çin'in Wuhan kentinde meydana gelen virüs zamanla Avrupa'ya ve oradan da tüm dünyaya yayılmıştır. Pandeminin başlangıcında bunun sadece Çin'le sınırlı olduğu düşünülse de birkaç ay içerisinde tüm dünya pandemi ile mücadele için önlem almak zorunda kalmıştır.

Pandemi bulaşma hızı arttıkça ülkelerde tam kapanma ve karantina uygulamaları devreye girmiştir. Aşıların 2020 yılı içerisinde etkin bir şekilde devreye sokulamaması, üretimin yanı sıra sosyal hayatın da durmasına neden olmuştur. Bunun bir sonucu olarak da üretim yapamayan işletmeler, çalışanlarını ücretsiz izne gönderirken, işsizlik maaşı için sosyal güvence şartlarını sağlayamayan milyonlarca işsiz oluşmuştur.

ILO verilerine göre 2020 yılında tüm dünyadaki çalışma saatleri bir önceki yıla göre \%8,8 oranında azalırken; bu oranın 250 milyon tam zamanlı istihdama denk geldiği belirtilmektedir. Yine ILO’ya göre istihdam kayıpları 2009 küresel ekonomik krizindeki kayıpların 4 katı büyüklüğündedir. ${ }^{23}$

Öyle ki liberal doktrinin hüküm sürdüğü $\mathrm{ABD}$ bile şart aranmaksızın tüm vatandaşlarına ekonomik destek paketleri açıklamak zorunda kalmıştır. Aşılanma başlayana kadar üç farklı dönemde vatandaşlarına direkt nakdi yardımda bulanan ABD Hazinesi acil eylem planı kapsamında hem çalışamayanlara hem de işletme sahiplerine 350 milyar \$ nakit desteği sağlamıştır. ${ }^{24}$

Pandeminin neden olduğu işsizlik sorunu Türkiye gibi gelişmekte olan ülkelerde de sosyal sorun halini almıştır. Öyle ki Türkiye Nisan 2020 yılında İş Kanunu’na

\footnotetext{
${ }^{22}$ Donna Lu, "Universal Basic Income Seems to Improve Employment and Well-Being”, New Scientist, May 6, 2020, https://www.newscientist.com/article/2242937-universal-basic-income-seems-to-improveemployment-and-well-being/.

${ }^{23}$ ILO, "ILO Monitor: Covid-19 and the World of Work", 2021, s.1-2.

24 US Treasury, "Covid-19 Economic Relief", U.S. Department of the Treasury, 2021, https://home.treasury.gov/policy-issues/coronavirus.
} 
eklediği geçici madde ile yürürlüğe soktuğu İşten çıkarma yasağı ve kısa çalışma ödeneği uygulamasını ${ }^{25} 30$ Haziran 2021 yılına kadar sürdürmüştür.

Covid-19'un Avrupa Birliği işgücü piyasalarına etkisi Tablo 1'deki istatistiklerde belirtilmektedir. Tablo 1'de 35 ülkenin istihdam ve işsizlik oranların verilmiştir. 2015 yılından 2019 yılına dek Çekya ve Türkiye hariç tüm ülkelerde işsizlik oranı azalma eğilimindeyken istihdam oranı artış göstermektedir. Veriler dikkatli incelendiğinde ise 2019 yılında 2020 yılına geçişte tüm ülkelerde hem işsizlik oranları artmış hem de istihdam oranları azalmıştır. AB 27 ülkeleri ortalama işsizlik oranları 2019 yılında \%6,8'den 2020 yılında \%7,2'ye yükselmiştir. ${ }^{26}$

Tablo 1. İstihdam ve Isşsizlik Oranları \% (2011-2020)

\begin{tabular}{|c|c|c|c|c|c|c|c|c|}
\hline \multirow[b]{2}{*}{ Ülkeler } & \multicolumn{2}{|c|}{2011} & \multicolumn{2}{|c|}{2018} & \multicolumn{2}{|c|}{2019} & \multicolumn{2}{|c|}{2020} \\
\hline & 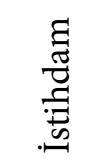 & 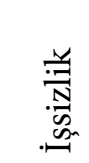 & 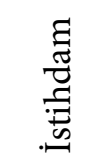 & 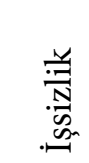 & 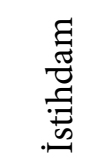 & 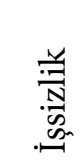 & 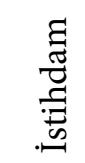 & 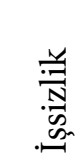 \\
\hline Belçika & 61,9 & 7,2 & 64,5 & 6,0 & 65,3 & 5,4 & 64,7 & 5,6 \\
\hline Bulgaristan & 58,4 & 11,4 & 67,7 & 5,3 & 70,1 & 4,3 & 68,5 & 5,2 \\
\hline Çekya & 65,7 & 6,8 & 74,8 & 2,3 & 75,1 & 2,1 & 74,4 & 2,6 \\
\hline Danimarka & 71,6 & 7,9 & 74,1 & 5,3 & 75,0 & 5,1 & 74,4 & 5,8 \\
\hline Almanya & 72,7 & 5,9 & 75,9 & 3,5 & 76,7 & 3,2 & 76,2 & 3,9 \\
\hline Estonya & 65,3 & 12,6 & 74,8 & 5,4 & 75,3 & 4,6 & 73,7 & 7,0 \\
\hline İrlanda & 60,0 & 15,7 & 68,6 & 5,9 & 69,5 & 5,1 & 67,7 & 5,8 \\
\hline Yunanistan & 55,1 & 18,1 & 54,9 & 19,5 & 56,5 & 17,5 & 56,3 & 16,5 \\
\hline İspanya & 58,0 & 21,5 & 62,4 & 15,4 & 63,3 & 14,2 & 60,9 & 15,6 \\
\hline Fransa & 63,9 & 8,9 & 65,3 & 9,1 & 65,6 & 8,5 & 65,3 & 8,1 \\
\hline Hirvatistan & 55,2 & 14,0 & 60,6 & 8,5 & 62,1 & 6,7 & 62,0 & 7,6 \\
\hline İtalya & 56,8 & 8,5 & 58,5 & 10,8 & 59,0 & 10,2 & 58,1 & 9,4 \\
\hline Kibris & 67,6 & 8,1 & 68,6 & 8,6 & 70,5 & 7,3 & 69,9 & 7,8 \\
\hline Letonya & 60,8 & 16,5 & 71,8 & 7,6 & 72,3 & 6,5 & 71,6 & 8,4 \\
\hline Litvanya & 60,2 & 15,7 & 72,4 & 6,3 & 73,0 & 6,5 & 71,6 & 8,8 \\
\hline Lüksemburg & 64,6 & 4,9 & 67,1 & 5,6 & 67,9 & 5,6 & 67,2 & 6,8 \\
\hline Macaristan & 55,4 & 11,1 & 69,2 & 3,7 & 70,1 & 3,5 & 69,7 & 4,3 \\
\hline Malta & 57,9 & 6,4 & 71,9 & 3,7 & 73,1 & 3,7 & 73,8 & 4,3 \\
\hline Hollanda & 74,2 & 5,0 & 77,2 & 3,8 & 78,2 & 3,4 & 77,8 & 3,9 \\
\hline Avusturya & 71,1 & 4,6 & 73,0 & 4,9 & 73,6 & 4,6 & 72,4 & 5,4 \\
\hline Polonya & 59,3 & 9,8 & 67,4 & 3,9 & 68,2 & 3,3 & 68,7 & 3,2 \\
\hline Portekiz & 63,8 & 13,3 & 69,7 & 7,3 & 70,5 & 6,7 & 69,0 & 7,1 \\
\hline Romanya & 59,3 & 7,5 & 64,8 & 4,3 & 65,8 & 4,0 & 65,6 & 5,2 \\
\hline Slovenya & 64,4 & 8,3 & 71,1 & 5,2 & 71,8 & 4,5 & 70,9 & 5,0 \\
\hline Slovakya & 59,3 & 13,7 & 67,6 & 6,6 & 68,4 & 5,8 & 67,5 & 6,8 \\
\hline Finlandiya & 69,0 & 7,9 & 72,1 & 7,5 & 72,9 & 6,8 & 72,1 & 7,9 \\
\hline İsveç & 73,6 & 8,0 & 77,4 & 6,5 & 77,1 & 7,0 & 75,5 & 8,5 \\
\hline
\end{tabular}

25 TBMM, "Yeni Koronavirüs (Covid-19) Salgınının Ekonomik ve Sosyal Hayata Etkilerinin Azaltılması Hakkında Kanun ile Bazı Kanunlarda Değiş̧iklik Yapılmasına Dair Kanun”, No: 7244, 2020.

${ }^{26}$ Eurostat, "Database - Employment and unemployment (LFS) - Eurostat", erişim 29 Temmuz 2021, https://ec.europa.eu/eurostat/web/lfs/data/database. 


\begin{tabular}{|l|l|l|l|l|l|l|l|l|}
\hline İzlanda & 78,5 & 7,1 & 85,1 & 2,8 & 84,1 & 3,6 & 80,3 & 5,7 \\
\hline Norveç & 75,3 & 3,3 & 74,8 & 3,9 & 75,3 & 3,8 & 74,7 & 4,5 \\
\hline İsviçre & 78,3 & 4,5 & 80,1 & 4,9 & 80,5 & 4,5 & 79,9 & 5,0 \\
\hline İngiltere & 69,3 & 8,2 & 74,7 & 4,1 & 75,2 & 3,8 & $:$ & $:$ \\
\hline Karadăg & 45,8 & 19,8 & 54,7 & 15,5 & 56,0 & 15,4 & 50,3 & 18,3 \\
\hline Makedonya & 43,9 & 31,6 & 51,7 & 21,0 & 54,7 & 17,4 & 54,7 & 16,6 \\
\hline Sirbistan & 45,4 & 23,6 & 58,8 & 13,3 & 60,7 & 10,9 & 61,3 & 9,5 \\
\hline Türkiye & 48,4 & 9,0 & 52,0 & 11,1 & 50,3 & 14,0 & 47,5 & 13,4 \\
\hline
\end{tabular}

Kaynak: Database - Employment and unemployment (LFS) Eurostat, 2021.

Bir yandan işsizlik artarken diğer yandan haftalık ortalama çalışılan süre azalma eğilimine girmiştir. Eurostat verilerine göre 2019 haftalık ortalama çalışma saati yılının dördüncü çeyreğinde bir önceki çeyreğe oranla \%5 azalma gösterirken, bu azalmanın büyük kısmı kadın çalışanlarda görülmüştür. Haftalık ortalama çalışma süresinde en büyük azalma \%12,4 ile Avusturya'da gerçekleşmiştir. ${ }^{27}$

Covid-19'un işgücü piyasalarındaki bir diğer etkisi ise sağlık endişesiyle işsizlerin iş arama faaliyetlerine katılmamasıdır. Eurostat verilerine göre AB'nde \%9,3 parttime ve $\% 2,5$ full-time olmak üzere işsiz olan fakat iş aramayan $\% 11,8$ 'lik bir kesim oluşmuştur. ${ }^{28}$

Virüsün bulaşması ile devreye sokulan karantina ve kapanma önlemleri üretimin durma noktasına gelmesine neden olmuş ve bazı ülkelerde zorunlu ihtiyaçlar $\mathrm{d}_{1}$ şında üretimlerin durdurulmasına karar verilmiştir. Öyle ki Covid-19'un etkilerinin tüm dünyada hissedilmeye başlandığı Mart 2020'de hizmetler sektörünün yanı sıra bazı otomotiv fabrikaları da üretime ara vermek zorunda kalmıştır. ${ }^{29}$

Şekil 1. AB Kamusal Sosyal Harcamaların GSYİH İçindeki Oranı

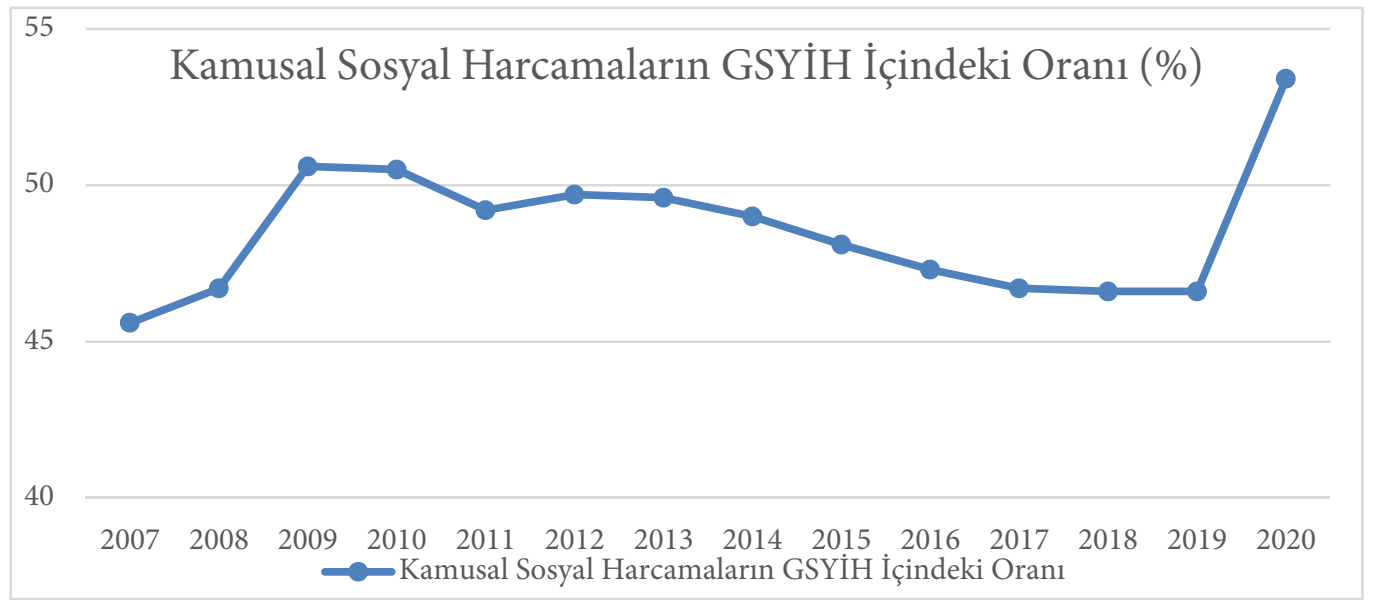

Kaynak: The European Economy since the Start of the Millennium, Eurostat, 2021.

AB’nde Mart 2020-Mayıs 2021 arasında Covid-19 kaynaklı 840 bin ölüm gerçekleşmiştir. Öyle ki Mart ayının sonundan itibaren ölüm sayılarında görülen yüksek

27 Eurostat, "Hours of Work - Quarterly Statistics", 2021, https://ec.europa.eu/eurostat/statisticsexplained/index.php?title=Hours_of_work_-_quarterly_statistics.

28 Eurostat, "Key Figures on the Impact of the COVID-19 Crisis on the Labour Market", 2021, https://ec.europa.eu/eurostat/statistics-

explained/index.php?title=Key_figures_on_the_impact_of_the_COVID-19_crisis_on_the_labour_market.

${ }^{29}$ Jan Maarten de Vet vd., "Impacts of the COVID-19 Pandemic on EU Industries", Study Requested by the ITRE Committee - European Parliament, March 2021, s.8-10. 
artışlar temel ihtiyaçlar dışında üretimi ikinci plana itmiştir. ${ }^{30}$

Şekil 1'de Covid-19'un kamusal sosyal harcamalar üzerindeki etkisi gösterilmektedir. 2009 ekonomik kriziyle birlikte \%50,6 ile zirve yapan kamusal sosyal harcamalar 2019 yılına kadar istikrarlı bir şekilde azalmıştır. 2019 yılı mart ayında patlak veren Covid-19 ve önlemleri kapsamında sosyal harcamaların devreye sokulmasıyla \%53,4 gibi 2009 ekonomik krizinde dahi yapılmayan düzeyde harcamalara başvurulmuştur. ${ }^{31}$

Tablo 2'de ise ülkelerin Covid-19 döneminde istihdamın desteklenmesine yönelik veriler bulunmaktadır. Mart ayında başlayan kısıtlamalarla birlikte ülkelerin işgücü piyasalarını desteklemeye yönelik politikaları hız kazanırken; Örneğin Belçika devleti Mart 2020'de 900 bin istihdama direkt katkıda bulunurken bulaşma oranlarının zirve yaptığı Nisan 2020'de 1 milyon 145 bin istihdama katkıda bulunmuştur. 2020 yılının Mayıs ayında katkı sağlanan istihdam sayısının 916 bin olurken; Covid-19 aşısının bulunması ve aşılanmanın hızlanmasıyla 2021 Mayıs ayında direkt katkı sağlanan istihdam sayısı 257 bine düşmüştür. ${ }^{32}$

Tablo 2: Covid-19 Sürecinde Kamu Tarafından Desteklenen İstihdam Sayıları

\begin{tabular}{|l|l|l|l|l|l|l|}
\hline \multirow{2}{*}{ Ülkeler } & Mart & \multicolumn{2}{|l}{ Nisan } & Kasım & Aralık & Ocak \\
\cline { 2 - 7 } & 2020 & 2020 & 2021 & 2020 & 2020 & 2021 \\
\hline Belçika & 929.714 & 1.145 .571 & & 465.107 & 349.435 & 371.360 \\
\hline Bulgaristan & 89.460 & 143.051 & & 137.695 & 128.662 & 127.749 \\
\hline Danimarka & 206.430 & 243.491 & & 237 & & \\
\hline Almanya & 2.459 .974 & 5.953 .413 & 2.340 .943 & 2.389 .814 & 2.671 .278 & 3.292 .634 \\
\hline Estonya & 33.508 & 121.003 & & & & 12.968 \\
\hline İlanda & 72.059 & 430.802 & & 272.400 & 320.800 & 352.700 \\
\hline Yunanistan & & 808.673 & & 728.641 & & \\
\hline İspanya & & 2.314 .020 & & 373.128 & 228.330 & 228.371 \\
\hline Fransa & 6.700 .445 & 8.385 .605 & & 3.118 .263 & 2.517 .767 & 2.257 .981 \\
\hline Hirvatistan & 511.244 & 583.471 & 127.241 & 154.443 & 163.972 & 159.114 \\
\hline İtalya & 4.327 .669 & 5.404 .790 & & 1.774 .496 & 1.715 .149 & \\
\hline Kibris & 146.852 & 178.787 & & 41.368 & 46.998 & \\
\hline Letonya & 23.085 & 44.417 & & 18.981 & 32.891 & 46.139 \\
\hline Litvanya & 107.965 & 169.824 & 112.956 & 46.469 & 92.311 & 132.867 \\
\hline Lüksemburg & 182.498 & & & & & \\
\hline Macaristan & & 27.084 & & 108.703 & 101.328 & 107.410 \\
\hline Malta & & 26.829 & & 62.248 & 63.227 & 27.658 \\
\hline Hollanda & 2.569 .000 & 2.428 .000 & & 1.161 .000 & 1.144 .000 & 526.974 \\
\hline Avusturya & 515.740 & 1.037 .041 & & 349.728 & 363.551 & 390.740 \\
\hline Polonya & & 401.659 & & 21.702 & 10.549 & 5.199 \\
\hline Portekiz & 160.587 & 786.157 & & & & \\
\hline Romanya & & & & & & \\
\hline
\end{tabular}

\footnotetext{
30 Eurostat, "Weekly Death Statistics", 2021, https://ec.europa.eu/eurostat/statisticsexplained/index.php?title=Weekly_death_statistics.

${ }^{31}$ Eurostat, "The European Economy since the Start of the Millennium - Government Expenditure to GDP Ratio down since 2010", 2021, https:/ec.europa.eu/eurostat/cache/digpub/european_economy/bloc4b.html?lang=en.

${ }^{32}$ Eurostat, "Overview - COVID-19 - Eurostat", 2021, https://ec.europa.eu/eurostat/web/covid-19/overview.
} 


\begin{tabular}{|l|l|l|l|l|l|l|}
\hline Slovenya & 119.866 & 181.968 & & 61.286 & 64.254 & 57.896 \\
\hline Slovakya & 369.666 & 464.059 & 470.983 & 273.433 & 263.454 & 485.529 \\
\hline Finlandiya & 73.973 & 183.976 & & 76.384 & 96.577 & \\
\hline İsveç & 210.229 & 438.492 & 83.205 & 131.936 & 127.393 & 103.676 \\
\hline
\end{tabular}

Kaynak: Overview-COVID-19 Eurostat, 2021.

Covid-19 genelde tüm yaşamı özelde ise çalışma hayatını o denli hızlı etkilemiştir ki birçok $\mathrm{AB}$ üyesi daha erken müdahale için farklı kararlar almak zorunda kalmıştır. Örneğin Şubat 2020'de Belçika'da kamu tarafından desteklenen istihdam sayısı 134 bin iken, Şubat 2020 'de yani bir ay sonra 929 bin sayısına yükselmiştir. ${ }^{33}$ Ülkelerin sahip olduğu farklı sosyo-ekonomik altyap $\mathrm{AB}$ içinde uyumlu karar alınmasını güçleştirmiştir.

$\mathrm{Bu}$ farklılığı ortadan kaldırmak ve Covid-19 pandemisinin olumsuz etkilerini daha hızlı giderebilmek için 23 Nisan 2020'de toplanan AB liderleri üye ülkelere ekonomik destek sağlayabilmek için $\mathrm{AB}$ Kurtarma paketinin oluşturulmasına karar vermiştir. İlk olarak 750 milyar Euro değerinde AB gelecek nesiller girişimi oluşturularak Pandeminin olumsuz etkilerine yönelik istikrarlı bir plan ortaya konmuştur. Daha sonra kurtarma paketine ilaveten 1 trilyon $€$ değerinde AB 2021-2027 uzun süreli bütçesi kabul edilerek; dijital ve yeşil dönüşüm yatırımları desteklenme kararı alınmıştır. Bu programlara ek olarak 540 milyar $€$ değerinde çalışanlar, işletmeler ve üye ülkeler için destek fonları kabul edilerek toplam 2.364 trilyon $€$ değerinde kamusal destek programı ilan edilmiştir. ${ }^{34}$

Bulaşma riskinin zirve yaptığı, Covid-19 aşısının henüz bulunmadığı 2020 yılında kısa adı SURE olan The Temporary Support to Mitigate Unemployment Risks in an Emergency adında bir program devreye sokulmuştur. Avrupa Komisyonu SURE'un, kendi topraklarında Covid-19 salgınının olumsuz ekonomik ve sosyal sonuçlarıyla mücadele etmek için önemli finansal araçları harekete geçirmesi gereken üye ülkeler için devreye sokulduğunu belirtmektedir. Üye ülkelerin istihdamı korumak amacıyla talep etmesi durumunda, 100 milyar Euro'ya kadar finansal borç uygulaması devreye girmektedir. ${ }^{35}$

Avrupa Komisyonu Başkanı Ursula Von Meyer 25 Mayıs 2021 itibariyle SURE programı kapsamında destek alan ülke sayısını 19, yapılan toplam nakdi destek miktarı ise 94 milyar $€$ olarak açıklamıştır. Özellikle Bulgaristan ve Estonya gibi ekonomik zorluklarla baş etmeye çalışan üyelerin de bu destekten faydalandığını belirten Meyer; SURE kapsamında 30 milyon çalışanın yanı sıra 2,5 milyon firmanın da bu fondan desteklendiğini ifade etmektedir. ${ }^{36}$

\section{Sonuç}

Çalışmanın geleceği tartışmaları genellikle post-endüstriyel toplum olgusu etrafında şekillenmektedir. Bununla birlikte endüstri toplumunun miadını doldurduğu ve dolayısıyla post-endüstriyel toplumdan bahsedilmesi gerektiği vurgusu ilk

\footnotetext{
${ }^{33}$ Eurostat, "Overview - COVID-19 - Eurostat".

34 Eurostat, "COVID-19: The EU's Response to the Economic Fallout", 2021, https://www.consilium.europa.eu/en/policies/coronavirus/covid-19-economy/.

35 Eurostat, "Support to Mitigate Unemployment Risks in an Emergency (SURE)", Text, European Commission, 2021, https://ec.europa.eu/info/business-economy-euro/economic-and-fiscal-policycoordination/financial-assistance-eu/funding-mechanisms-and-facilities/sure_en.

36 Eurostat, "€14.1 Billion under SURE to 12 Member States", Text, European Commission, 2021, https://ec.europa.eu/commission/presscorner/detail/en/ip_21_2592.
} 
kez Daniel Bell tarafından dile getirilmiştir. Bell'e göre endüstri toplumu emek değer teorisine dayanırken post-endüstriyel toplumda artık yenilik yaratmanın kaynağı bilgidir ve bilgi teknolojisi ile bilgiyi kullanan herkesin hayatı sonsuza dek değișecektir.

Andre Gorz da Bell gibi bilgiye vurgu yaparak bilgi ekonomisi olgusunu ön plana çıkarmaktadır. Maddesiz üretim olarak adlandırdığı bilgi ekonomisine göre; postendüstriyel toplumda bilgi bir kere üretildikten sonra yeniden üretmek için katlanılan maliyet sıfıra yakındır. Gorz’a büyük zenginlik kaynağı olarak görülen doğrudan emeğin bu özelliğini kaybettiğini dolayısıyla zenginliğin ölçümünde de kullanılamayacağını ifade etmektedir. Yine Gorz'a göre post-endüstriyel toplumda çalışma sürelerinin mübadele değerinin anlamını yitirdiği ve bu nedenle refah, üretim ve çalışma ilişkilerinin yeniden kurulması gerekmektedir.

Çalışmanın geleceği tartışmalarına 1970'li yıllardan itibaren dâhil olan Alvin Toffler göre ise 1960'lı yıllarda ivmelenen teknolojik gelişmeler üçüncü dalga toplumlarını oluştururken, ikinci dalga toplumu ile birbirinden kesin çizgilerle ayrılan üretici ve tüketici ilişkisini tekrar belirsizleştirmiştir. Teknoloji bir yandan üretimi ve üretime katılımı kolaylaştırırken diğer yandan talep edilen istihdamın azalmasına neden olmaktadır. Toffler'e göre üçüncü dalga toplumunun baskın hale gelmesiyle birlikte insanların ikinci dalga toplumundaki gibi tam gün prensibiyle çalışmayacağı ve dolayısıyla çalışma sürelerinin hızla azalacağı bir dönem başlayacaktır.

Jeremy Rifkin ise 1994 yılında yayınladığ eseriyle endüstri toplumuyla baskın hale gelen bildiğimiz anlamda çalışmanın sonuna gelindiği ve toplumumuzun buna uyum sağlamasının önemine vurgu yapmaktadır. Rifkin, teknolojinin gelişmesiyle birlikte insanlık tarihinde ilk defa, üretimde insan emeğine olan talep sistemli bir şekilde azaltılabilme imkanı doğduğunu belirtmektedir.

Çalışmanın geleceğine yönelik teorilerin büyük çoğunluğu endüstri toplumuna özgü tipik çalışmanın sonuna gelindiğine ya da gelmek üzere olduğuna odaklanmaktadır. Post-endüstriyel toplum teorisyenleri, klasik anlamda çalışmanın ortadan kalkması ile toplumda meydana gelebilecek işsizlikle bağlantılı sosyal sorunlara dikkat çekerek, kamu müdahalesinin zorunluluğuna vurgu yapmaktadır. Bununla birlikte kamu müdahale çeşitleri ise genellikle çalışmanın, çalışmak isteyen tüm paydaşlar arasında bölüştürülmesi ya da temel gelir gibi sürekli nakdi destek uygulamaları etrafında şekillenmektedir. İşsizlik yardımı, işsizlik maaşı ya da şartsız temel gelir pasif işgücü piyasası politikalarını oluştururken; istihdamın paylaştırılması, çalışma sürelerinin kısaltılması ya da kamu istihdam arttırma uygulamaları aktif işgücü piyasası politikalarını oluşturmaktadır.

Temel gelir programlarının yüksek maliyeti, ülkelerin çalışma saatlerini düşürerek istihdamı paylaştırma ya da kamu istihdam politikaları yoluyla işsizliği azaltma yolunu tercih etmelerine neden olmaktadır. Düşük maliyeti ve sürdürülebilir olması aktif işgücü piyasası politikalarını ön plana çıkarmaktadır. Aktif işgücü piyasası politikaları; istihdam yaratıldığı oranda başarılı olabilmektedir. Ekonomik kriz, savaş vb. olağanüstü dönemlerde ise kamunun tek müdahale aracı gelir destek programları olmaktadır. 
Nitekim benzer bir müdahale ihtiyacı, 2019 yılında Çin'in Wuhan kentinde ortaya çıkan Covid-19 pandemisi ile ortaya çıkmıştır. Çin, tüm kentleri karantina altına alsa da virüsün yayılma hızını engelleyememiş ve tüm dünya aynı sorunla uğraşmak zorunda kalmıştır.

Covid-19 virüsünün hava ve temas yoluyla bulaşması; tam kapanma ya da karantina uygulamalarını zorunlu kılmıştır. Tam kapanma ve karantina uygulamaları ise toplam talebi düşürürken; temel ihtiyaçlar dışında üretimin durmasına neden olmuştur. Durma noktasına gelen üretim, uzaktan çalışma uygulamaları ile sınırlı da olsa devam ettirilebilmiştir.

Fütüristtik olduğu iddia kitlesel işsizlik olgusu pandemi sürecinde geçici de olsa sosyal hayatı ters yüz etmiştir. Toplam talebin hızla azalması, geçici de olsa kitlesel işsizliği tetiklemiştir. ILO verilerine göre 2020 yılında tüm dünyadaki çalışma saatleri bir önceki yıla göre \%8,8 oranında azalırken; bu oranın 250 milyon tam zamanlı istihdama denk geldiği hesaplanmaktadır. Yine ILO'ya göre istihdam kayıpları 2009 küresel ekonomik krizindeki kayıpların 4 katı büyüklügündedir.

Kamu müdahale araçlarından olan istihdam yaratarak işsizliği azaltma uygulamaları Covid-19 pandemisinde mümkün olmayınca; devletler sahip oldukları ekonomik imkânlar doğrultusunda nakit destek programları uygulamaya almıştır.

ABD gibi liberal iktisat doktrinin sosyal hayatı şekillendirdiği ülkeler bile karşılıksız destek programları açıklamak zorunda kalmıştır. Normal şartlarda karşılıksız desteğin ekonomi piyasalarının ruhuna aykırı olduğu kabul edilen ABD, aşılanma başlayana kadar üç farklı dönemde vatandaşlarına direkt nakdi yardımda bulunmuş, ABD Hazinesinin düzenlediği acil eylem planı kapsamında hem çalışamayanlara hem de işletme sahiplerine 350 milyar \$ nakit desteği sağlamıştır.

Diğer yandan Türkiye gibi gelişmekte olan ülkeler de Covic-19 pandemisinden olumsuz etkilenmiş ve piyasalara müdahale ihtiyacı doğmuştur. Türkiye bu sorunla mücadele edebilmek için İş Kanunu'na geçici madde ekleyerek, Nisan 2020 tarihinden Haziran 2021 tarihine kadar işten çıkarmaya yasaklarken, geçici işsizlik ödeneği uygulamasını devreye sokmuştur.

Başka ülkelerde durum böyleyken; AB 27 ülkeleri özelinde veriler incelendiğinde ise ortalama işsizlik oranları 2019 yılında \%6,8'den Covid-19'un etkisiyle 2020 yılında \%7,2'ye yükselmiştir. Covid-19'un neden olduğu kitlesel işsizlik derinlemesine incelendiğinde önemli bir oranda işsizin, sağlık endişesiyle iş arama faaliyetlerine ara verdiği görülmektedir. Eurostat verilerine göre $A B$ ’nde $\% 9,3$ part-time ve $\% 2,5$ full-time olmak üzere işsiz olan fakat iş aramayan $\% 11,8$ 'lik bir kesim oluşmuştur

Var olan işlerin paylaştırılması ya da istihdam yaratmanın mümkün olmadığ 1 Covid-19 pandemisi döneminde; uzaktan çalışamayan ve sosyal güvencesi olmayan milyonlarca kişi ise kamu desteğine ihtiyaç duymuştur. AB Covid-19 etkilerini azaltmak ve üye ülke vatandaşlarına destek olmak için toplam 2.364 trilyon $€$ değerinde kamusal destek programı ilan edilmiştir

Bulaşma riskinin zirve yaptığı, Covid-19 aşısının henüz bulunmadığı 2020 yılında kisa adı SURE olan The Temporary Support to Mitigate Unemployment Risks in an Emergency adında bir program devreye sokulmuştur. Avrupa Komisyonu SURE'un, kendi topraklarında Covid-19 salgınının olumsuz ekonomik ve sosyal 
sonuçlarıyla mücadele etmek için önemli finansal araçları harekete geçirmesi gereken üye ülkeler için devreye sokulduğu belirtmektedir. Üye ülkelerin istihdamı korumak amaciyla talep etmesi durumunda, 100 milyar Euro'ya kadar finansal borç uygulaması devreye girmektedir.

Tüm bu destek uygulamalarına rağmen yapılan desteklerin yeterli olmadığı ya da desteklerden en büyük payın işverenlere ayrıldığı tartışmaları devam etmektedir. Öyle ki birçok üye ülkede desteklerin yetersiz olduğu gerekçe gösterilerek, karantina ve kapanmaların sona erdirilmesi için protestolar düzenlenmiştir.

Covid-19 pandemisinin neden olduğu geçici kitlesel işsizlik çalışmanın geleceğine yönelik tartışmaları gündeme getirerek; sadece özel sektör ile toplumsal barışın sağlanmasının önündeki zorlukları belirginleştirmiştir. Kar mantığı ile hareket eden özel sektör, pandemi döneminde zararını azaltma yollarını ararken, kamu otoriteleri etkileri aza indirerek sosyal barışı sağlamaya çalışmıştır. $A B$, farklı üye profilleri yüzünden pandeminin başında etkin müdahale edememiş olsa da ilerleyen dönemlerde aldığı birlik kararı ve uygulamaları ile etkileri hafifletmeyi başarmiştır.

Sonuç olarak Covid-19'un neden olduğu geçici işsizlik durumunda bile piyasanın ya da özel sektör uygulamalarının sorunun çözümünde yeterli olmadığı, kamu otoritelerinin müdahalelerine olan ihtiyaç gözlemlenmiştir. Başka bir ifade ile anlatılacak olursa, çalışmanın geleceği tartışmalarında kamu otoritelerinin dâhil olmadığı makro planların başarı şansı oldukça düşüktür.

\section{Kaynakça}

Bell, Daniel. The Coming of Post-Industrial Society: a Venture in Social Forecasting. Special Anniversary ed. New York: Basic Books, 1999.

Brynjolfsson, Erik ve Andrew Mcafee. İkinci Makine Çağı: Akıllı Teknolojiler Devrinde Çalışma, İlerleme ve Refah. Çev., Levent Göktem. İstanbul: Türk Hava Yolları Yayınları, 2014.

Delaunay, Jean-Claude ve J. Gadrey. Services in Economic Thought: Three Centuries of Debate. International Studies in the Service Economy, V. 3. Boston: Kluwer Academic Publishers, 1992.

Eurostat. "Database - Employment and unemployment (LFS) - Eurostat". Erişim 29 Temmuz 2021. https://ec.europa.eu/eurostat/web/lfs/data/database.

Eurostat. "Hours of Work - Quarterly Statistics", 2021. https://ec.europa.eu/ eurostat/statistics-explained/index.php?title=Hours_of_work_-_quarterly_statistics.

Eurostat. "Key Figures on the Impact of the COVID-19 Crisis on the Labour Market", 2021. https://ec.europa.eu/eurostat/statistics-explained/index.php?title= Key_figures_on_the_impact_of_the_COVID-19_crisis_on_the_labour_market.

Eurostat. "Overview - COVID-19 - Eurostat", 2021. https://ec.europa.eu/eurostat/ web/covid-19/overview.

Eurostat. "The European Economy since the Start of the Millennium Government Expenditure to GDP Ratio down since 2010”, 2021. https://ec.europa.eu/eurostat/cache/digpub/european_economy/bloc4b.html?lang=en.

Eurostat. "Weekly Death Statistics", 2021. https://ec.europa.eu/eurostat/statisticsexplained/index.php?title=Weekly_death_statistics. 
Eurostat. "Support to Mitigate Unemployment Risks in an Emergency (SURE)". Text. European Commission, 2021. https://ec.europa.eu/info/businesseconomy-euro/economic-and-fiscal-policy-coordination/financialassistance-eu/funding-mechanisms-and-facilities/sure_en.

Eurostat. "€14.1 Billion under SURE to 12 Member States". Text. European Commission, 2021. https://ec.europa.eu/commission/presscorner/detail/en/ ip_21_2592.

Eurostat. "COVID-19: The EU's Response to the Economic Fallout", 2021. https://www.consilium.europa.eu/en/policies/coronavirus/covid-19economy/.

Bernstein, Jared. "Getting Back to Full Employment: On the Economy". On the Economy: Jared Bernstein Blog. Erişim 5 Ağustos 2020. http://jaredbernsteinblog.com/getting-back-to-full-employment/.

Gorz, André. Elveda Proletarya. Çev. Hülya Tufan. İstanbul: AFA Yayınları, 1986. Gorz, Andre. Kapitalizm, Sosyalizm, Ekoloji: Yönelim Bozuklukları, Arayışlar. Çeviren Işık Ergüden. İstanbul: Ayrıntı, 1993.

Gorz, André. Maddesiz: Bilgi Değer ve Sermaye. Çev., Işık Ergüden. İstanbul: Ayrint1, 2011.

Gorz. Andre. Yaşadiğımız Sefalet: Kurtuluş Çareleri. Çev., Nilgün Tutal Cheviron. İstanbul: Ayrınt1, 2001.

ILO. "ILO Monitor: Covid-19 and the World of Work", 2021.

Keynes, John Maynard. "Economic Possibilities for Our Grandchildren (1930)". Essays in Persuasion. New York: Harcourt Brace, 1932: 358-372.

Leontief, Wassily. "National Perspective: The Definition of Problems and Oppurtinities". The long-Term Impact of Technology on Employment and Unemployment. Washington: National Academies Press, 1983: 3-7.

Lu, Donna. "Universal Basic Income Seems to Improve Employment and WellBeing”. New Scientist. 6 Mayıs 2020. https://www.newscientist.com/ article/2242937-universal-basic-income-seems-to-improve-employmentand-well-being/.

“Moore’s Law: Computer Science”, Encyclopedia Britannica. Erişim 10 Ocak 2020. https://www.britannica.com/technology/Moores-law.

Rifkin, Jeremy. The End of Work: The Decline of the Global Labor Force and the Dawn of the Post-Market Era. New York: G.P. Putnam's Sons, 1995.

Schwab, Klaus. Dördüncü Sanayi Devrimi. Çev., Zülfü Dicleli. İstanbul: Optimist, 2017.

Schwab, Klaus ve Nicholas Davis. Shaping the Future of the Fourth Industrial Revolution. New York: Currency Book, 2018.

Smith, Adam. "An Inquiry into the Nature and Causes of the Wealth of Nations". Adam Smith. Der., Edwin Cannan, 1904. https://www.journals.uchicago.edu/ doi/10.1086/251119.

TBMM. "Yeni Koronavirüs (Covid-19) Salgınının Ekonomik ve Sosyal Hayata Etkilerinin Azaltılması Hakkında Kanun ile Bazı Kanunlarda Değişiklik Yapilmasina Dair Kanun”, No: 7244, 2020.

Toffler, Alvin. Üçüncü Dalga. Çev., Ali Seden. İstanbul: Altın kitaplar, 1996.

US Treasury. “Covid-19 Economic Relief”. U.S. Department of the Treasury, 2021. https://home.treasury.gov/policy-issues/coronavirus. 
Vet, Jan Maarten de, Daniel Nigohosyan, Jorge Nunez Ferrer, Ann-Kristin Gross, Silvia Kuehl ve Michael Flickenschild. "Impacts of the COVID-19 Pandemic on EU Industries". Study Requested by the ITRE Committee - European Parliament, March 2021.

Waters, Malcolm. Key Sociologists: Daniel Bell. Routledge, 2002. 